\title{
Effect of Work Design and Organizational Culture on the Performance of Jayapura Flight Polytechnic Employees
}

\author{
Akilla Makanuay ${ }^{1}$, Jemi V. Palpialy ${ }^{2}$ \\ ${ }^{1,2}$ Program Study Electrical Engineering Airport, Polytechnics Flight Jayapura, Indonesia
}

Corresponding Author: Akilla Makanuay

\begin{abstract}
Organizations need to do a good and structured work design to create parts or portions of work that are balanced between one employee and another so that later it does not cause jealousy between one employee and another employee who thinks that the workload is heavier among other employees. With the creation of a good work design, a good organizational culture will also be created, the sense of tolerance of workers will be stronger because the division of the portion of the work is equal, so that there is no jealousy between employees and the creation of a good, orderly work environment so that the goals organization was achieved. The expected results from this study are to determine the effect of work design and organizational culture on the performance of Jayapura Poltekbang employees so that it is hoped that problems related to work design, organizational culture, and employee performance can be resolved and for future employee performance improvements.
\end{abstract}

Keywords: Work Design, Organizational Culture, Employee Performance, Jayapura Poltekbang

\section{INTRODUCTION}

An organization has a goal to develop and progress by predetermined goals so that it can compete with other organizations. For that, an organization needs work productivity to achieve predetermined goals. "Productivity is the ratio between output (results) and input (input)" According to Purnomo, (2015: 5). Increased productivity is made possible by an increase in efficiency (time, materials, labor), work systems, production techniques, and an increase in the skills of the workforce.

Organizations need to do a good and structured work design to create parts or portions of work that are balanced between one employee and another so that later it does not cause jealousy between one employee and another employee who thinks that the workload is heavier among other employees. With the creation of a good work design, a good organizational culture will also be created, the sense of tolerance of workers will be stronger because the division of the portion of the work is equal so that there is no jealousy between employees and the creation of a good, orderly work environment so that the goals organization was achieved.

However, currently, the main problem in employment in Indonesia is low labor productivity. The productivity of human resources or labor is very important because labor productivity has a big role in determining the success or failure of a business. Indonesia can be said to have a low level of work productivity when compared to other more developed Asian countries, which raises concerns, given that Indonesia is increasingly required to be able to compete in the international market due to the stronger free trade system. Indonesia can no longer rely on traditional sources of comparative advantages, such as cheap labor and natural resources. Improvements 
in various ways are very necessary; the most important improvement is in the field of human resources because human resources are a major factor in the operational activities of the organization. Indonesia needs to develop a dynamic comparative advantage, namely qualified, productive and professional human resources (HR).

Low productivity is often related to the level of education, so it is assumed that the higher a person's level of education, the higher the level of productivity he may be able to achieve.

Several factors cause the Jayapura Poltekbang staff to not perform optimally, including the work design and organizational culture that are not in line with organizational goals.

Based on the problems studied, the purpose of this study is to carry out the effectiveness and efficiency of the parenting styles of cadets related to character building within the Jayapura Aviation Polytechnic campus, while the purpose of this study is to determine whether work design and organizational culture simultaneously have a positive and significant effect on performance Jayapura Poltekbang employees so they can find out whether the work design and organizational culture partially have a positive and significant effect on the performance of Jayapura Poltekbang employees.

\section{LITERATURE REVIEW}

\subsection{Understanding Work Design}

A previous job must be designed or done a job design, this is to have a positive effect on increasing work productivity and no less important, namely the effectiveness and efficiency of both work patterns and in terms of labor financing. To be able to carry out the strategic functions of the human resources department and achieve organizational goals through its programs, this department integrates policies and practices with the organization's strategic plan (Porter, 2008), providing opportunities for employees to make their work more meaningful and in line with the strategic direction of the organization. One of them is through job design. Employees will be willing and able to work properly if they are placed in a position according to their interests and abilities. Human resource management is closely related to the motto "The Right Man on the Right Place and the Right Time".

So at the right time, this department must be able to ensure that the employee is placed in the right position according to his interests and abilities. Work or tasks are a bridge between employees and the organization. So the job must be designed appropriately to produce and maintain a productive work unit, foster motivation, increase job satisfaction and manage work stress. (Sulipan, 2000). Job design is the process of determining specific tasks to be carried out, the methods used in carrying out these tasks, and how the work is related to other jobs in the organization (Mondy, 2008).

Therefore organizations need to have a work system that can support the achievement of organizational goals effectively and efficiently which can stimulate employees to work productively, reduce boredom and increase job satisfaction, job design is sometimes used to deal with work stress faced by employees.

\subsection{Understanding Organizational Culture}

According to Jacques (in Shaliha 2017: 14) organizational culture or organizational culture is: "The costumery or traditional ways of thinking and doing things, which are shared to a greater or lesser extent by all members of the organization and which new number must learn and at least partially accept to be accepted at the core of the service of the firm". (a traditional way of thinking and doing something, which is shared by all members of the organization and new members must learn or at least partially accept it so that they are accepted as part of the organization/organization). According to Edwar (in Nayati 2012: 10) culture is a comprehensive complex 
combination consisting of knowledge, belief, art, morals, law, customs, and various other capabilities as well as any habits that a human being acquires as part of society.

Organizational culture as a guideline for controlling the behavior of organizational members certainly has useful functions and benefits for an organization. Organizational culture is useful for building in redesigning organizational management control systems, namely as a tool to create commitment so that managers and employees want to carry out strategic planning programming, budgeting, controlling, monitoring, evaluation, etc., Mondy and Noe (in Rinai, 2011: 7). The function of organizational culture according to Robbins (in Rian 2011: 8 ) is as follows:

a. Culture creates a clear distinction between one organization and another.

b. Culture brings a sense of identity to members of the organization.

c. Culture facilitates the emergence of commitment to a broad range of individual self-interests.

d. Culture is the social glue that helps unite the organization by providing proper standards for employees to practice.

e. Culture as a meaning-making and control mechanism that guides and shapes employee attitudes and behavior can understand how to achieve organizational goals.

Assessment of organizational culture cannot be separated from the context of the overall organizational behavior. Organizational behavior can be defined as the attitudes and actions shown by individuals in an organization. Therefore, the study of organizational culture as an aspect of organizational behavior scientifically has an important meaning because it can contribute to building the overall construction of organizational behavior as applied science. The importance of studying organizational culture pragmatically can be seen from its role.

In this context, organizational culture is a framework that guides behavior and decision-makers. Organization members and direct their actions to achieve organizational goals. Thus, it is clear that the study of organizational culture has an important meaning both in terms of scientific interests and from a pragmatic point of view.

\section{METHOD}

The type of research that the authors use in this research is quantitative research. Quantitative data analysis is used when researchers use a survey research approach, experimental research, quantitative research and several other studies that contain. data in the form of numbers (Manullang and Manimbing, 2014: 2017)

The variables in this study are emotional intelligence and self-confidence as independent variables, and productivity as the dependent.

Table.1. Operational variables.

\begin{tabular}{|c|c|c|c|c|}
\hline No & Variable & Definition & Indicator & Scale \\
\hline 1. & Design Work & $\begin{array}{l}\text { The process of determining the tasks that } \\
\text { must be carried out by the incumbent, the } \\
\text { right to regulate the work, and the } \\
\text { responsibilities of a work package. }\end{array}$ & $\begin{array}{l}\text { a. The significance of the task } \\
\text { b. Ability development } \\
\text { c. Diversity Of task }\end{array}$ & Likert \\
\hline 2. & Organizational culture & $\begin{array}{l}\text { A system of shared meaning held by } \\
\text { members that differentiates one organization } \\
\text { from another }\end{array}$ & $\begin{array}{ll}\text { a. } & \text { Innovation and taking risk } \\
\text { b. } & \text { Result Orientation } \\
\text { c. } & \text { Aggressiveness } \\
\text { d. } & \text { Stability } \\
\end{array}$ & Likert \\
\hline 3 & Performance & $\begin{array}{l}\text { A description of the level of achievement } \\
\text { of the implementation of an activity / } \\
\text { program / policy in realizing the goals, } \\
\text { objectives, mission and vision of the } \\
\text { organization as stated in the strategic } \\
\text { planning of an organization. }\end{array}$ & $\begin{array}{ll}\text { a. } & \text { Technical ability } \\
\text { b. } & \text { Conceptual skills } \\
\text { c. } & \text { Interpersonal relationship skills }\end{array}$ & Likert \\
\hline
\end{tabular}

Data collection can be done in various ways and from various sources. The data collection techniques used were questionnaires and interviews. 


\section{Questionnaire (Questionnaire)}

It is a primary data collection technique that is carried out by giving a set of questions to respondents to be answered (Sugiyono, 2011). The questionnaire is an efficient data collection technique and is suitable for a large number of respondents. In this study, a questionnaire with a Likert scale was used.

\section{Interview (Interview)}

It is one of the techniques for collecting data and information through communicating directly with respondents, namely people who are designated as data sources (Sinulingga, 2014).

\section{Documentation Study}

Is a secondary data collection process. This study collects data and information from various literary sources such as special books or magazines, journals, and documents that are relevant to the problem to be studied to complement the primary data.

\section{RESULTS}

\subsection{Description of Respondent Characteristics}

In this study, primary data was collected which were taken from 45 respondents to determine their responses to the implementation of the appropriate work design and organizational culture in improving the performance of Jayapura Aviation Polytechnic Employees. The characteristics of respondents that will be described below reflect how the respondents studied include gender, age, last education, and period of selling.

\section{a) Characteristics of Respondents by} Gender.

\begin{tabular}{|c|c|c|c|}
\hline 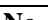 & & & \\
\hline & & & rercentage \\
\hline 1 & Man & 32 & $71.11 \%$ \\
\hline 2 & Woman & 13 & $28.89 \%$ \\
\hline \multicolumn{2}{|c|}{ Total } & 45 & $100,0 \%$ \\
\hline
\end{tabular}

Based on Tables 2, it can be seen that the gender of the respondents was mostly male as many as 32 people or $71.11 \%$. Meanwhile, at least 13 respondents were female or $28.89 \%$.

\section{b) Characteristics of Respondents by Age}

Tables 3. Ages
\begin{tabular}{|l|l|l|l|}
\hline No & Ages & Total & Percentage \\
\hline $\mathbf{1}$ & 20-30 years & 9 & $20 \%$ \\
$\mathbf{2}$ & 31-40 years & 11 & $24.4 \%$ \\
$\mathbf{3}$ & 41-50 years & 23 & $51.1 \%$ \\
$\mathbf{4}$ & 51 years olders & 2 & $4.5 \%$ \\
\hline Total & $\mathbf{4 5}$ & $\mathbf{1 0 0 , 0} \%$ \\
\hline
\end{tabular}

\section{b. Reliability Testing}

Reliability is the degree of accuracy, precision or accuracy shown by the measurement instrument. Questionnaire items are said to be reliable or reliable if someone's answer to the questionnaire is consistent. In this study, to determine whether the questionnaire was reliable or not, using Alpha Cronbach. The questionnaire is said to be reliable if Cronbach's alpha is $>0.60$ and not reliable if it is equal to or below 0.60 .

The reliability of the questionnaire questions that the author has submitted to the respondents in this study will be seen in the Reliability Statistics table which is presented in the table below:

Tables 4. Reliability Test (X1) Work Design

\begin{tabular}{|l|l|}
\hline Reliability Statistics & N of Items \\
\hline Cronbach's Alpha & 9 \\
\hline .825 & \\
\hline
\end{tabular}

From the table 4.30 above, the results of the SPSS output show that the Cronbach's Alpha value is $0.825>0.60$, so it can be concluded that the questions that have been presented to respondents consisting of 9 statement items on the work design variable are reliable or are said to be reliable.

Tables 5. Reliability Test (X2) Organizational Culture.

\begin{tabular}{|l|l|}
\hline \multicolumn{2}{|l|}{ Reliability Statistics } \\
\hline Cronbach's Alpha & N of Items \\
\hline .760 & 10 \\
\hline
\end{tabular}

\subsection{Classic Assumption Testing}

The normality test aims to test whether in a regression, confounding variables or residuals are normally 
distributed or not. Regression models have either normal or near normal data distribution.

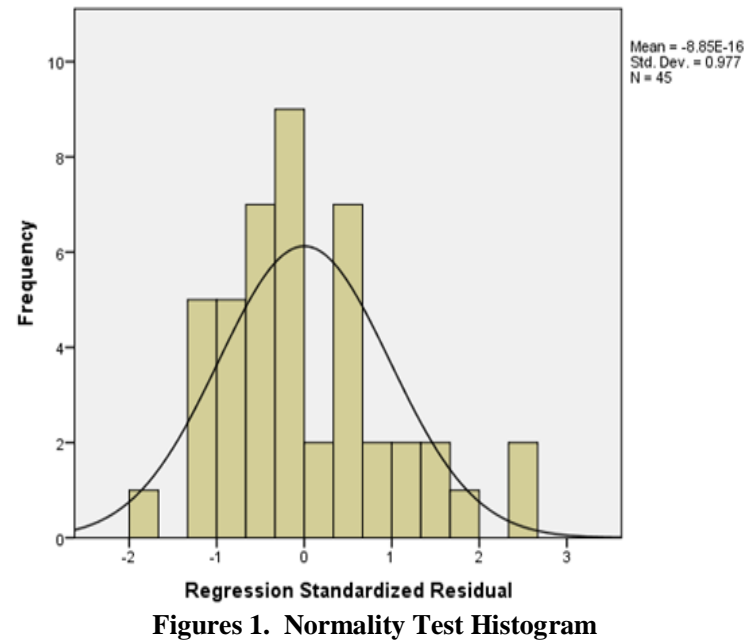

Based on Figure 1 above, the results of the data normality test show that the data has been normally distributed, where the histogram image has a line forming a bell and has a convexity balanced in the middle.

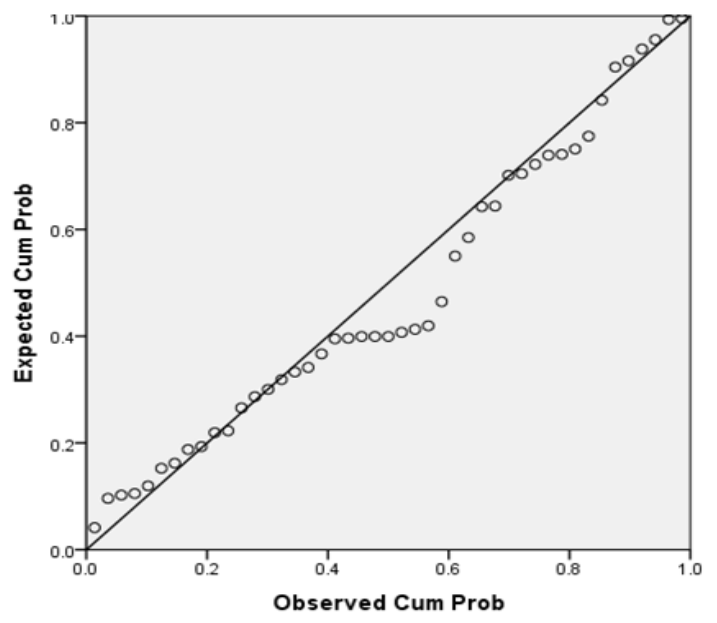

Figures 2. PP Plot Normality Test

Based on Figures 2 above, then for the results of testing the normality of data using the PP Plot image, it is seen that the data points that spread are around the diagonal line so that the data is normally distributed. From the two images above, it can be concluded that after the data normality test was carried out, the data for work design variables, organizational culture and performance were normally distributed.

\section{CONCLUSION}

Based on the results of the analysis and discussion that has been carried out in this study, the researchers draw the following conclusions:

1. Work design and organizational culture simultaneously have a positive and significant effect on the performance of Jayapura Aviation Polytechnic employees

2. Work design and organizational culture partially have a positive and insignificant effect on the performance of Jayapura Aviation Polytechnic employees, while organizational culture partially has a positive and significant effect on the performance of Jayapura Aviation Polytechnic employees.

\section{Acknowledgement: None}

\section{Conflict of Interest: None}

\section{Source of Funding: None}

\section{REFERENCES}

1. Sunarto.2005. Mengelola Karyawan. Yogyakarta: Amus.

2. Simamora, Henry. 2004. Manajemen Sumber Daya Manusia. Edisi Ketiga. Yogyakarta: STIE Yogyakarta.

3. Gallup. 2010. Employee engagement. What is your ration?. http://www.gallup. com/ consulting/121535/employee-engagementoverview-brochure.aspx. Diakses tanggal 19 April 2019.

4. Azwar, S. 2007. Sikap Manusia Teori dan Pengukurannya. adisi 2. Pustaka Pelajar. Yogyakarta.

5. Gibson, dkk. 1987. Organisasi: Perilaku, Struktur, Proses, Edisi Kelima, Jilid 1, Alih Bahasa Djarkasih. Erlangga. Jakarta.

6. Mondy, R. Wayne. 2008. Manajemen Sumber Daya Manusia. Jakarta: Penerbit Erlangga

7. Rivai, Veithzal, Sagala, Jauvani. 2010. Manajemen Sumber Daya Manusia untuk Perusahaan. Rajawali Pers. Jakarta.

8. Jurnal Akuntansi, Manajemen Bisnis Dan Issn 1829 - 9857 Sektor Publik (Jambsp) 74 Jambsp Vol. 9 No. 1 - Oktober 2012: 74 97 
Akilla Makanuay et.al. Effect of work design and organizational culture on the performance of Jayapura flight polytechnic employees.

9. Peran Perancangan Pekerjaan (Job Design) Pada Employee Engagement Emeralda Ayu Kusuma Emeralda.Kusuma@Gmail.Com Sekolah Tinggi Ilmu Ekonomi Indonesia Surabaya

10. Syafaruddin, Alwi. 2001. Manajemen Sumber Daya Manusia: Strategi Keunggulan Kompetitif, Yogyakarta; BPFE Yogyakarta.

11. Fried, Y., and Ferris, G. R. 1987. 'The Validity of the Job Characteristics Model. A Review and Meta-Analysis' Personnel Psychology 40.

12. Wibowo., 2007, Manajemen Kinerja, PT. Raja Grafindo Persada: Jakarta
13. Sianipar., 2003, Teknik Analisa Manajemen, Lembanga Administrasi Negara: Jakarta

14. Mangkunegara, A.A. Prabu., 2009, Manajemen Sumber Daya Manusia Perusahaan, PT. Remaja Rosdakarya: Bandung.

How to cite this article: Makanuay A, Palpialy JV. Effect of work design and organizational culture on the performance of Jayapura flight polytechnic employees. International Journal of Research and Review. 2021; 8(4): 336-341. DOI: https://doi.org/10.52403/ijrr.20210440

$* * * * * *$ 